\title{
Implementasi Nilai-Nilai Karakter Siswa dalam Pembelajaran \\ Contextual Teaching And Learning (CTL) pada Pelajaran Tematik di SD Unggulan 'Aisyiyah Taman Harapan Curup
}

\author{
Muslimah \\ Institut Agama Islam Negeri (IAIN) Curup \\ muslimahnausheen628@gmail.com \\ Mutia \\ Institut Agama Islam Negeri (IAIN) Curup \\ mutianasir24@gmail.com
}

\begin{abstract}
This research is motivated by the phenomenon of character education which lately has not been carried out optimally and the effectiveness of formal education has not been effective. Everywhere acts of violence and rounding or quarrels occur. This is very worrying for children. So that the teacher has an important role in forming and developing the character of students in the school environment, especially in carrying out learning activities. CTL learning is one of the learning models suitable for implementing student character education in thematic subjects. So the purpose of this study is to study more deeply about what character values are contained in thematic lessons through learning Contextual Teaching and Learning in Primary Elementary Schools 'Aisyiyah Taman Harapan Curup and its implementation. This study uses a descriptive qualitative approach. Data collection techniques used in the form of interviews, observation, and documentation. Data analysis uses Miles and Huberman interactive models, namely data reduction, data presentation, and conclusion drawing. Test the validity of the data using triangulation techniques. The results of the research that have been carried out show that: (1) the character values in CTL learning in the thematic study of sub-themes 1 and 3 of learning 3 has 12 character values developed. These values are religious, disciplined, hard work, creative, independent, curiosity, love for the country, respect for achievement, caring for the social, responsible, friendly / communicative, and tolerance; (2) the form of character education implementation in CTL learning is realized in each thematic learning activity sub-themes 1 and 3 which are integrated with CTL aspects in it such as praying, praying, using learning media, conducting experiments, giving assignments, asking questions, presenting the results of the discussion, singing Indonesian songs, and doing practice questions.
\end{abstract}

AR-RIAYAH : Jurnal Pendidikan Dasar vol. 2, no. 2, 2018

STAIN Curup - Bengkulu| pISSN2580-362X;e ISSN2580-3611

http://journal.staincurup.ac.id/index.php/JPD 
Keywords: Character Education, Primary School Children, Digital Era

Abstrak : Penelitian ini dilatarbelakangi oleh fenomena pendidikan karakter yang akhir-akhir ini belum terlaksana dengan optimal dan belum efektifnya pendidikan formal. Di mana-mana terjadi tindakan kekerasan dan pembulian atau pertengkaran. Hal ini sangat mengkhawatirkan bagi anak-anak. Sehingga guru memiliki peran penting dalam membentuk dan mengembangkan karakter peserta didik di lingkungan sekolah terutama dalam melaksanakan kegiatan pembelajaran. Pembelajaran CTL merupakan salah satu model pembelajaran yang cocok untuk menerapkan pendidikan karakter siswa pada mata pelajaran tematik. Sehingga tujuan penelitian ini adalah untuk mengkaji lebih mendalam tentang, nilai-nilai karakter apa saja yang terdapat dalam pelajaran tematik melalui pembelajaran Contextual Teaching and Learning di SD Unggulan 'Aisyiyah Taman Harapan Curup; dan implementasinya. Penelitian ini menggunakan pendekatan kualitatif deskriptif. Teknik pengumpulan data yang digunakan berupa wawancara, observasi, dan dokumentasi. Analisis data menggunakan model interaktif Miles dan Huberman yaitu reduksi data, penyajian data, dan penarikan kesimpulan. Uji keabsahan data menggunakan triangulasi teknik. Hasil penelitian yang telah dilaksanakan menunjukkan bahwa: (1) nilai-nilai karakter dalam pembelajaran CTL pada pelajaran tematik subtema 1 dan 3 pembelajaran ke-3 terdapat 12 nilai-nilai karakter yang dikembangkan. Nilai tersebut yaitu religius, disiplin, kerja keras, kreatif, mandiri, rasa ingin tahu, cinta tanah air, menghargai prestasi, peduli sosial, tanggung jawab, bersahabat/komunikatif, dan toleransi; (2) bentuk implementasi pendidikan karakter pada pembelajaran CTL diwujudkan dalam setiap kegiatan pembelajaran tematik subtema 1 dan 3 yang diintegrasikan dengan aspek-aspek CTL di dalamnya seperti berdo'a, sholat, menggunakan media pembelajaran, melakukan percobaan, pemberian tugas, mengajukan berbagai pertanyaan, mempersentasikan hasil diskusi, menyanyikan lagu indonesia raya, dan mengerjakan soal latihan.

Kata Kunci : Nilai Karakter, Tematik, Contextual Teaching and Learning

\section{PENDAHULUAN}

Pendidikan adalah usaha sadar dan terencana untuk mewujudkan suasana belajar dan proses pembelajaran agar peserta didik secara aktif mengembangkan potensi dirinya untuk memiliki kekuatan spiritual keagamaan, 
pengendalian diri, kepribadian, kecerdasan, akhlak mulia, serta keterampilan yang diperlukan dirinya, masyarakat, bangsa, dan negara. ${ }^{1}$

Sedangkan tujuan pendidikan nasional menurut UU. No. 20 Tahun 2003 tentang Sistem Pendidikan Nasional pada Pasal 3 menyatakan bahwa: "Pendidikan Nasional berfungsi untuk mengembangkan kemampuan dan membentuk watak serta peradaban bangsa yang bermartabat dalam rangka mencerdaskan kehidupan bangsa, bertujuan untuk berkembangnya potensi peserta didik agar menjadi manusia yang; beriman dan bertaqwa kepada Tuhan Yang Maha Esa, berakhlak mulia, sehat, berilmu, cakap, kreatif, mandiri, dan menjadi Warga Negara yang demokratis dan bertanggung jawab. ${ }^{2}$ Berdasarkan tujuan pendidikan nasional tersebut, maka pendidikan karakter adalah salah satu tujuan dari pendidikan nasional itu sendiri yaitu membentuk watak serta peradaban yang bermartabat, beriman dan bertaqwa kepada Tuhan Yang Maha Esa, berakhlak mulia, sehat, berilmu, cakap, kreatif, mandiri, dan menjadi Warga Negara yang demokratis dan bertanggung jawab.

Pendidikan karakter memiliki esensi dan makna yang sama dengan pendidikan moral dan akhlak. Tujuannya adalah untuk membentuk pribadi anak supaya menjadi manusia yang baik, yaitu warga masyarakat dan negara yang baik. Manusia, masyarakat dan warga negara yang baik adalah menganut nilainilai sosial tertentu yang banyak dipengaruhi oleh budaya masyarakat dan bangsanya. ${ }^{3}$

Dalam dunia pendidikan, terdapat tiga ranah yang harus dikuasai oleh siswa, yaitu ranah kognitif, afektif, dan psikomotorik. Ranah kognitif berorientasi pada penguasaan ilmu pengetahuan dan teknologi, ranah afektif berkaitan dengan attitude, moralitas, spirit, dan karakter, sedangkan ranah psikomotorik berkaitan dengan keterampilan bersifat prosedural dan cenderung mekanis.

Dalam realitas pembelajaran di sekolah, usaha untuk menyeimbangkan ketiga ranah tersebut memang selalu diupayakan, tetapi pada kenyataannya yang dominan adalah ranah kognitif, kemudian psikomotorik. Akibatnya, adalah peserta didik kaya akan kemampuan bersifat hard skill, tetapi miskin soft skill

\footnotetext{
${ }^{1}$ Hamdani, Dasar-Dasar Kependidikan (Bandung: CV Pustaka Setia, 2011).

2 Novan Ardy Wiyani, Konsep, Praktek \& Strategi Membumikan Pendidikan Karakter Di SD (Jogjakarta: Ar-Ruzz Media, 2013).

3 Jamal Ma'mur Asmani, Buku Panduan Internalisasi Pendidikan Karakter Di Sekolah (Yogyakarta: DIVA Press, 2012).
} 
karena ranah afektif terabaikan. Gejala ini tampak pada output pendidikan yang memiliki kemampuan intelektual tinggi, pintar, juara kelas, tetapi miskin kemampuan membangun relasi, kekurangmampuan bekerja sama, dan cenderung egois, serta menjadi pribadi yang tertutup. Padahal, pendidikan pada esensinya merupakan sebuah upaya membangun kecerdasan manusia, baik kecerdasan kognitif, afektif, maupun psikomotorik. Oleh karena itu, pendidikan secara terus menerus dibangun dan dikembangkan agar menghasilkan generasi yang unggul; unggul dalam ilmu, iman, dan amal. ${ }^{4}$

Salah satu kunci sukses dalam mewujudkan pendidikan yang berkualitas dan berkarakter tentunya tidak luput dari peran seorang guru. Guru yang memiliki kompetensi profesionalitas untuk dapat menciptakan proses pembelajaran yang relevan dan sesuai dengan perkembangan dan tuntutan masyarakat serta teknologi.

Terkait dengan pendidikan karakter, setiap satuan pendidikan dapat mengefektifkan alokasi waktu yang tersedia dalam rangka menerapkan penanaman nilai-nilai budaya dengan menggunakan metode pembelajaran yang aktif. Hal ini dilakukan guru sejak mengawali pembelajaran, selama proses berlangsung pemberian tugas-tugas mandiri dan terstruktur baik yang dilakukan secara individu maupun kelompok, serta penilaian hasil belajar. ${ }^{5}$

SDUA adalah salah satu sekolah yang menerapkan pendidikan karakter dalam proses pembelajaran. Dilihat dari kemampuan guru dalam mengajar dan persiapan bahan pembelajaran seperti, Rencana Pelaksanaan Pembelajaran (RPP), guru sudah memasukkan beberapa nilai-nilai karakter seperti religius, nasionalisme, mandiri, gotong royong dalam RPP yang akan digunakan untuk pedoman pembelajaran dan guru juga menerapkannya dalam proses pembelajaran. Sikap siswa dalam proses pembelajaran sangat berpartisipasi, antusias dan tertib dalam mengikuti proses pembelajaran. ${ }^{6}$

Pendidikan karakter dalam kurikulum 2013, bertujuan untuk meningkatkan mutu proses pendidikan, yang mengarah pada pembentukan budi pekerti dan akhlak mulia peserta didik secara utuh, terpadu, dan seimbang, sesuai dengan standar kompetensi kelulusan pada setiap satuan pendidikan.

\footnotetext{
${ }^{4}$ Ma'mur Asmani.

${ }^{5}$ Daryanto Suryatri Darmiatu, Implementasi Pendidikan Karakter Di Sekolah (Yogyakarta: Gava Media, 2013).

6 Wawancara dengan Waka Kurikulum SDUA (SD Unggulan 'Aisyiyah Taman Harapan Curup), February 5, 2018.
} 
Melalui implementasi kurikulum 2013 yang berbasis kompetensi sekaligus berbasis karakter, dengan pendekatan tematik dan kontekstual diharapkan peserta didik mampu secara mandiri meningkatkan dan menggunakan pengetahuannya, mengkaji dan menginternalisasi serta mempersonalisasi nilai-nilai karakter dan akhlak mulia sehingga terwujud dalam perilaku sehari-hari. ${ }^{7}$

Dalam implementasi kurikulum 2013, pendidikan karakter dapat diintegrasikan dalam seluruh pembelajaran pada setiap bidang studi yang terdapat dalam kurikulum. Materi pembelajaran yang berkaitan dengan norma atau nilai-nilai pada setiap bidang studi perlu dikembangkan, dieksplisitkan, dihubungkan dengan konteks kehidupan sehari-hari. Dengan demikian, pendidikan nilai, dan pembentukan karater tidak hanya dilakukan pada tataran kognitif, tetapi menyentuh internalisasi, dan pengalaman yang nyata dalam kehidupan sehari-hari. Penciptaan lingkungan yang kondusif dapat dilakukan melalui berbagai variasi metode, yang mencakup: penguasaan, pembiasaan, pelatihan, pembelajaran, pengarahan dan keteladanan. Berbagai variasi metode tersebut berpengaruh terhadap pembentukan karakter peserta didik.

Contextual Teaching and Learning (CTL) adalah suatu strategi pembelajaran yang menekankan kepada proses keterlibatan siswa secara penuh untuk dapat menemukan materi yang dipelajari dan menghubungkannya dengan situasi kehidupan nyata sehingga mendorong siswa untuk dapat menerapkannya dalam kehidupan mereka. ${ }^{10}$ Adapun kelebihan dari model pembelajaran CTL: a) memberikan kesempatan pada siswa untuk dapat maju terus sesuai dengan potensi yang dimiliki siswa sehingga siswa terlibat aktif dalam proses belajar mengajar; b) siswa dapat berfikir kritis dan kreatif dalam mengumpulkan data, memahami suatu isu dan memecahkan masalah dan guru dapat lebih kreatif; c) menyadarkan siswa tentang apa yang mereka pelajari; d) pemilihan informasi berdasarkan kebutuhan siswa tidak ditentukan oleh guru; e) pembelajaran lebih menyenangkan dan tidak membosankan; f) membantu siwa bekerja dengan efektif dalam kelompok; g) terbentuk sikap kerja sama yang baik antar individu maupun kelompok. ${ }^{8}$ Sehingga strategi pembelajaran Contextual teaching and

\footnotetext{
7 Mulyasa, Pengembangan Dan Implementasi Kurikulum 2013 (Bandung: PT Remaja Rosdakarya, 2014).

8 Http://Machdans-Modelmodelpembelajaran.Blogspot.Co.Id/ Di Akses Pada Tanggal, 27 Maret 2018, Jam 15:12.
} 
Learning (CTL) sangat cocok sekali untuk menerapkan nilai-nilai karakter siswa dalam pembelajaran tematik yang terdapat dalam kurikulum 2013. ${ }^{9}$

\section{Pendidikan Karakter}

Karakter adalah watak, tabiat, akhlak, adab, atau ciri kepribadian seseorang yang terbentuk dari hasil internalisasi berbagai nilai kebajikan (virtues) yang diyakini dan digunakan sebagai landasan berpikir, bersikap dan bertindak. ${ }^{10}$ "Karakter dapat dimaknai sebagai cara berpikir dan berperilaku yang khas tiap individu untuk hidup dan bekerja sama, baik dalam lingkup keluarga, masyarakat, bangsa dan negara. Kata karakter diartikan sebagai perilaku yang tampak dalam kehidupan sehari-hari baik dalam bersikap maupun dalam bertindak." Menurut Scerenco mengatakan bahwa "karakter adalah sebagai atribut atau ciri-ciri yang membentuk dan membedakan ciri pribadi, ciri etis, dan kompleksitas mental dari seseorang, suatu kelompok atau bangsa. ${ }^{11}$

Pendidikan karakter pada intinya bertujuan membentuk bangsa yang tangguh, kompetitif, berakhlak mulia, bermoral, bertoleran, bergotong royong, berjiwa patriotik, berkembang dinamis, berorientasi ilmu pengetahuan dan teknologi yang semuanya dijiwai oleh iman dan takwa kepada Tuhan Yang maha Esa berdasarkan Pancasila.

\section{Nilai-Nilai Pembentuk Karakter}

Pendidikan karakter pada satuan pendidikan telah teridentifikasi 18 nilai yang besumber dari agama, Pancasila, budaya, dan tujuan pendidikan nasional yaitu: 1. Religius; 2. Jujur; 3. Toleransi; 4. Disiplin; 5. kerja keras; 6. kreatif; 7. Mandiri; 8. Demokratis; 9. Rasa ingin tahu; 10. Semangat Kebangsaan; 11. Cinta Tanah Air; 12. Menghargai Prestasi; 13. Bersahabat/Komunikatif; 14. Cinta Damai; 15. Gemar Membaca; 16. Peduli Lingkungan; 17. Peduli Sosial; 18. Tanggung Jawab. ${ }^{12}$

Pendidikan karakter melalui sekolah, tidak semata-mata pembelajaran pengetahuan semata, tetapi lebih dari itu, yaitu penanaman moral, nilai-nilai etika, estetika, budi pekerti yang luhur dan lain sebagainya. Dalam pendidikan karakter di sekolah, semua komponen harus dilibatkan, termasuk komponen-

9 Wina Sanjaya, Strategi Pembelajaran Berorientasi Standar Proses Pendidikan (Jakarta: Kencana, 2016).

${ }^{10}$ Ardy Wiyani, Konsep, Praktek \& Strategi Membumikan Pendidikan Karakter Di SD.

${ }^{11}$ Muchlas Samani and Harianto, Konsep Dan Model Pendidikan Karakter, (Bandung: PT remaja Rosdakarya, 2013).

12 Gunawan Heri, Pendidikan Karakter (Bandung: Alfabeta, 2012). 
komponen pendidikan itu sendiri, yaitu isi kurikulum, proses pembelajaran dan penilaian, kualitas hubungan, penanganan atau pengelolaan mata pelajaran, pengelolaan sekolah, pelaksanaan aktivitas atau kegiatan kokurikuler, pemberdayaan sarana prasarana, pembiayaan, dan etos kerja seluruh warga dan lingkungan sekolah.

Di samping itu, lingkungan masyarakat juga sangat mempengaruhi pembentukan karakter dan watak seseorang. Lingkungan masyarakat juga sangat mempengaruhi implementasi penanaman nilai-nilai keberagaman untuk pembentukan karakter anak.

\section{Tabel 1. Nilai-Nilai Karakter yang Bersumber dari Agama, Pancasila, Budaya, dan Tujuan Pendidikan Nasional ${ }^{13}$}

\begin{tabular}{|c|c|c|}
\hline No & Nilai & Deskripsi \\
\hline 1. & Religius & $\begin{array}{l}\text { Sikap dan perilaku yang patuh dalam melaksanakan ajaran agama } \\
\text { yang dianutnya, toleran terhadap pelaksanaan ibadah agama lain, } \\
\text { dan hidup rukun dengan pemeluk agama lain. }\end{array}$ \\
\hline 2. & Jujur & $\begin{array}{l}\text { Perilaku yang dilaksanakan pada upaya menjadikan dirinya } \\
\text { sebagai orang yang selalu dapat dipercaya dalam perkataan, } \\
\text { tindakan, dan pekerjaan. }\end{array}$ \\
\hline 3. & Toleransi & $\begin{array}{l}\text { Sikap dan tindakan yang menghargai perbedaan agama, suku, } \\
\text { etnis, pendapat, sikap, dan tindakan orang lain yang berbeda dari } \\
\text { dirinya. }\end{array}$ \\
\hline 4. & Disiplin & $\begin{array}{l}\text { Tindakan yang menunjukkan perilaku tertib dan patuh pada } \\
\text { berbagai ketentuan dan peraturan. }\end{array}$ \\
\hline 5. & Kerja keras & $\begin{array}{l}\text { Perilaku yang menunjukkan upaya sungguh-sungguh dalam } \\
\text { mengatasi berbagai hambatan belajar dan tugas, serta } \\
\text { menyelesaikan tugas dengan sebaik-baiknya. }\end{array}$ \\
\hline 6. & Kreatif & $\begin{array}{l}\text { Berfikir dan melakukan sesuatu untuk menghasilkan cara atau } \\
\text { hasil baru dari sesuatu yang telah dimiliki. }\end{array}$ \\
\hline 7. & Mandiri & $\begin{array}{l}\text { Sikap dan perilaku yang tidak mudah tergantung dengan pada } \\
\text { orang lain dalam menyelesaikan tugas-tugas. }\end{array}$ \\
\hline 8. & Demokrasi & $\begin{array}{l}\text { Cara berfikir, bersikap, dan bertindak yang menilai sama hak dan } \\
\text { kewajiban dirinya dan orang lain. }\end{array}$ \\
\hline 9. & Rasa ingin tahu & $\begin{array}{l}\text { Sikap dan tindakan yang selalu berupaya untuk mengetahui lebih } \\
\text { mendalam dalam dan meluas dari sesuatu yang dipelajarinya, } \\
\text { dilihat, dan didengar. }\end{array}$ \\
\hline 10. & $\begin{array}{c}\text { Semangat } \\
\text { kebangsaaan }\end{array}$ & $\begin{array}{l}\text { Cara berfikir, bertindak, dan berwawasan yang menempatkan } \\
\text { kepentingan bangsa dan negara di atas kepentingan diri dan } \\
\text { kelompoknya. }\end{array}$ \\
\hline 11. & Cinta tanah air & $\begin{array}{l}\text { Cara berfikir, bersikap, dan berbuat yang menunjukkan } \\
\text { kesetiaan, kepeduliaan, dan penghargaan yang tertinggi terhadap } \\
\text { bangsa, lingkungan fisik, sosial, budaya, ekonomi, dan politik } \\
\text { bangsa. }\end{array}$ \\
\hline 12. & Menghargai & Sikap dan tindakan yang mendorong dirinya untuk menghasilkan \\
\hline
\end{tabular}

${ }^{13}$ Narwanti, Pendidikan Karakter. 


\begin{tabular}{|c|c|c|}
\hline & prestasi & $\begin{array}{l}\text { sesuai yang berguna bagi masyarakat, dan mengakui, serta } \\
\text { menghormati keberhasilan orang lain. }\end{array}$ \\
\hline 13. & $\begin{array}{l}\text { Bersahabat/ko } \\
\text { munikatif }\end{array}$ & $\begin{array}{l}\text { Tindakan yang memperhatikan rasa senang berbicara, bergaul, } \\
\text { dan bekerja sama dengan orang lain. }\end{array}$ \\
\hline 14. & Cinta damai & $\begin{array}{l}\text { Sikap, perkataan, dan tindakan yang menyebabkan orang lain } \\
\text { merasa senang dan aman atas kehadiran dirinya. }\end{array}$ \\
\hline 15. & $\begin{array}{c}\text { Gemar } \\
\text { membaca }\end{array}$ & $\begin{array}{l}\text { Kebiasaan menyediakan waktu untuk membaca berbagai bacaan } \\
\text { yang memberikan kebajikan bagi dirinya. }\end{array}$ \\
\hline 16. & $\begin{array}{c}\text { Peduli } \\
\text { lingkungan }\end{array}$ & $\begin{array}{l}\text { Sikap dan tindakan yang selalu berupaya mencegah kerusakan } \\
\text { pada lingkungan alam di sekitarnya, dan mengembangkan upaya- } \\
\text { upaya untuk memperbaiki kerusakan alam yang sudah terjadi. }\end{array}$ \\
\hline 17. & Peduli sosial & $\begin{array}{l}\text { Sikap dan tindakan yang selalu ingin memberi bantuan pada } \\
\text { orang lain dan masyarakat yang membutuhkan. }\end{array}$ \\
\hline 18. & $\begin{array}{l}\text { Tanggung } \\
\text { jawab }\end{array}$ & $\begin{array}{l}\text { Sikap dan perilaku seseorang untuk melaksanakan tugas dan } \\
\text { kewajibannya, yang seharusnya dia lakukan, terhadap diri sendiri, } \\
\text { masyarakat, lingkungan (alam, sosial dan budaya), negara dan } \\
\text { Tuhan yang Maha Esa. }\end{array}$ \\
\hline
\end{tabular}

\section{Contextual Teaching Learning (CTL)}

Sanjaya mengungkapkan bahwa, Contextual Teaching and Learning (CTL) merupakan suatu strategi pembelajaran yang menekankan pada proses keterlibatan siswa secara penuh untuk menemukan materi yang dipelajari dan menghubungkannya dengan situasi kehidupan nyata sehingga mendorong siswa untuk dapat menerapkannya dalam kehidupan mereka. Dari definisi di atas dijelaskan bahwa siswa mampu menyerap pelajaran apabila mereka menangkap makna dalam materi akademis yang diterima, dan mereka menangkap makna dalam tugas-tugas sekolah jika mereka bisa mengaitkan informasi baru dengan pengetahuan dan pengalaman yang sudah mereka miliki sebelumnya”.

Komponen pembelajaran kontekstual, meliputi: 1) making meaningful connections (menjalin hubungan-hubungan yang bermakna), 2) doing significan work (mengerjakan pekerjaan-pekerjaan yang berarti), 3) self-regulated learning (melakukan proses pembelajaran di ataur sendiri), 4) collaborating (mengadakan kolaborasi), 5) critical and creatif thin king (berpikir kritis dan kreatif), 6) nurturing the individual (memberikan layanan secara individual), 7) reaching high standards (mengupayakan pencapaian standar yang tinggi), dan 8) using authentic assessment (menggunakan asesmen autentik). ${ }^{14}$

Ada tujuh prinsip pembelajaran Contextual Teaching and Learning (CTL) yang harus dikembangkan guru, yaitu: konstruktivisme, menemukan (Inquiry),

\footnotetext{
14 Rusman.
} 
bertanya (Questioning), masyarakat belajar (Learning Community), pemodelan (Modeling), refleksi (Reflection), dan penilaian nyata (Authentc Assessment).

\section{METODOLOGI PENELITIAN}

Jenis penelitian ini adalah penelitian deskriptif kualitatif. Penelitian kualitatif adalah jenis penelitian yang tidak mengedepankan perhitungan atau angka-angka dalam metode mengelola dan menginterpretasikan data. Subjek utama dalam penelitian ini adalah guru di SD Unggulan 'Aisyiyah Taman Harapan Curup. Teknik pengumpulan data yang digunakan berupa wawancara, observasi, dan dokumentasi. Analisis data menggunakan model interaktif Miles dan Huberman yaitu reduksi data, penyajian data, dan penarikan kesimpulan. Uji keabsahan data menggunakan triangulasi teknik.

\section{PEMBAHASAN} Nilai-Nilai Karakter yang Terdapat dalam Pelajaran Tematik Melalui
Pembelajaran Contextual Teaching and Learning (CTL)

\section{Keberagaman Budaya Bangsaku}

Berdasarkan hasil observasi, implementasi nilai-nilai karakter siswa melalui pembelajaran Contextual Teaching and Learning (CTL) pada pelajaran tematik subtema "Keberagaman Budaya Bangsaku" pada pembelajaran ke-3 materi perambatan bunyi terdapat dua belas nilai-nilai karakter yang teramati, nilai karakter tersebut antara lain:

a. Religius

Dalam kegiatan pembelajaran, nilai religius diterapkan pada saat memulai kegiatan belajar-mengajar, berdo'a sebelum memulai pembelajaran merupakan aktivitas yang pertama kali dilakukan. Demikian juga menjelang dalam mengakhiri pembelajaran, berdoa merupakan aktivitas yang terakhir kali dilakukan siswa-siswi sekolah. Selain menaati perintah agama, berdoa dapat menumbuhkan sugesti kepada diri siswa untuk lebih siap menerima ilmu yang akan dipelajari.

b. Disiplin

Nilai karakter disiplin diterapkan dalam proses pembelajaran dengan cara, sebelum memulai pembelajaran guru mengecek kehadiran siswa dengan menanyakan kepada peserta didik siapa yang tidak masuk. Kemudian guru juga memberikan contoh sikap disiplin seperti masuk kelas dengan tepat waktu dan menggunakan baju seragam yang rapi sesuai dengan peraturanperaturan yang ada di SD Unggulan 'Aisyiyah Taman Harapan Curup. Misalnya penggunaan baju batik atau baju seragam lainnya. 
c. Kerja Keras

Siswa berusaha dengan sungguh-sungguh dalam mengerjakan soal-soal latihan dan tugas kelompok yang diberikan. Siswa-siswi juga berusaha untuk bisa menyelesaikan tugas sesuai dengan waktu yang telah ditentukan.

d. Kreatif

Dalam materi perambatan bunyi, guru menggunakan media yang inovatif. Guru memberikan pertanyaan-pertanyaan yang berkenaan dengan perambatan bunyi untuk memancing gagasan siswa. Serta memberikan penilaian atas hasil kerja siswa dan memberikan penugasan. Hal ini dapat membentuk karakter kreatif siswa baik dalam berfikir, terampil, dan kreatif dalam mengemukakan pendapat.

e. Mandiri

Pembentukan karakter mandiri dilakukan dengan meminta peserta didik untuk menyelesaikan tugas yang diberikan secara individu, dan meminta peserta didik untuk mempresentasikan hasil diskusi yang telah diperoleh.

f. Rasa Ingin Tahu

Pembentukan karakter rasa ingin tahu melalui pemberian apersepsi, pada materi perambatan bunyi guru memberikan apersepsi dengan mengajukan beberapa pertanyaan yang berkaitan dengan perambatan bunyi. Hal ini dapat menumbuhkan rasa ingin tahu peserta didik terhadap materi.

g. Cinta Tanah Air

Penanaman karakter cinta tanah air yang diterapkan di SD Unggulan 'Aisyiyah Taman Harapan Curup dengan menyanyikan lagu indonesia raya dan lagu-lagu daerah.

h. Menghargai Prestasi

Pemberian reward merupakan salah satu cara guru untuk menghargai prestasi yang diperoleh peserta didik, serta dapat menumbuhkan motivasi belajar bagi siswa yang belum memperoleh prestasi agar lebih semangat dalam belajar.

i. Peduli Sosial

Pembentukan karakter peduli sosial dilakukan dengan pemberian tugas kelompok, dengan pemberian tugas kelompok maka siswa dapat bekerja sama dan saling tolong-menolong dalam memecahkan masalah yang diberikan oleh guru.

j. Tanggung Jawab

Dengan memberikan penguatan kepada peserta didik untuk menyelesaikan tugas dapat membentuk karakter tanggung jawab peserta didik. Serta 
karakter tanggung jawab dapat dilihat ketika peserta didik telah menyelesaikan tugas yang diberikan.

k. Bersahabat/Komunikatif

Semua peserta didik pada saat melakukan kegiatan kelompok dan diskusi tentang perambatan bunyi mereka terlihat saling bekerja sama untuk memecahkan masalah-masalah yang diberikan oleh guru dan berusaha untuk menyelesaikan secara bersama-sama. Dari sini dapat terlihat keakraban mereka terhadap antar sesama teman.

1. Toleransi

Penanaman karakter toleransi dalam proses pembelajaran dapat dilakukan melalui pembentukan kelompok yang berbeda, menyampaikan hasil diskusi, dan menanyakan hal-hal yang belum dipahami oleh siswa.

\section{Bersyukur Atas Keragaman}

Berdasarkan hasil observasi, implementasi nilai-nilai karakter siswa melalui pembelajaran Contextual Teaching and Learning (CTL) pada pelajaran tematik subtema "Bersyukur Atas Keragaman" pada pembelajaran ke-3 materi pemantulan dan penyerapan bunyi terdapat sepuluh nilai-nilai karakter yang teramati, nilai karakter tersebut antara lain:

a. Disiplin

Guru memberikan contoh sikap disiplin seperti masuk kelas dengan tepat waktu dan menggunakan baju seragam yang rapi sesuai dengan peraturanperaturan yang ada di SD Unggulan 'Aisyiyah Taman Harapan Curup. Misalnya, penggunaan baju batik atau baju seragam lainnya. Hal ini dilakukan agar peserta didik dapat mencontoh serta terbiasa untuk masuk kelas tepat waktu dan selalu menggunakan seragam sekolah dengan rapi. Serta menegur siswa yang melanggar aturan di kelas seperti, berbicara saat guru menjelaskan materi, mengganggu temannya saat belajar.

b. Kerja keras

Dari hasil observasi yang telah dilakukan, peneliti melihat bahwa siswa berusaha dengan sungguh-sungguh dalam mengerjakan soal-soal latihan dan tugas kelompok yang diberikan. Serta peneliti melihat siswa-siswi berusaha untuk bisa menyelesaikan tugas sesuai dengan waktu yang telah ditentukan.

c. Kreatif

Dalam penyampaian materi pemantulan dan penyerapan bunyi guru menggunakan media gambar sebagai alat bantu untuk menyampaikan materi agar mudah dipahami oleh peserta didik. Pembelajaran akan lebih menarik perhatian siswa sehingga dapat menumbuhkan motivasi belajar siswa dan 
kreatifitas siswa. Guru memberikan beberapa pertanyaan yang berkenaan dengan pemantulan dan penyerapan bunyi untuk memancing gagasan/ideide baru siswa. Serta memberikan penilaian dan penugasan.

d. Mandiri

Berdasarkan hasil observasi yang telah dilakukan, peneliti melihat guru memberikan latihan-latihan soal tentang pemantulan dan penyerapan bunyi secara individu, serta siswa diminta untuk mempersentasikan hasil diskusi, dan membuat laporan hasil percobaan secara mandiri.

e. Rasa ingin tahu

Dalam pembentukan karakter rasa ingin tahu siswa diberikan melalui pemberian apersepsi terlebih dahulu sebelum memasuki inti pembelajaran. Apersepsi yang diberikan dalam materi perambatan bunyi berupa pertanyaan-pertanyaan yang berkaitan dengan materi. Hal ini dapat membangkitkan semangat anak ketika memasuki pembelajaran dan membangkitkan rasa ingin tahu anak secara mendalam tentang materi.

f. Menghargai prestasi

Dari hasil observasi yang telah dilakukan peneliti melihat, guru memberikan hadiah kepada siswa-siswa yang bisa menyimpulkan pembelajaran yang telah dilakukan dan memberikannya kepada kelompok terbaik dalam bentuk point prestasi. Kemudian point prestasi tersebut ditulis dalam buku saku siswa. Serta memberikan penilaian atas hasil belajar siswa.

g. Peduli sosial

Dari hasil observasi, peneliti melihat bahwa pada saat peserta didik melakukan percobaan tentang pemantulan dan penyerapan bunyi. Mereka terlihat saling bekerja sama dan tolong menolong dalam melakukan percobaan agar dapat menyelesaikan tugas dan dapat memperoleh informasi dari hasil percobaan yang telah mereka lakukan. Dari hasil wawancara sebelumnya yang telah dilakukan oleh guru kelas IV beliau mengatakan bahwa, dengan memberikan tugas kelompok berupa kegiatan percobaan atau kegiatan praktik, maka mereka akan saling bekerja sama dan bergotong royong agar dapat menyelesaikan tugas percobaan tersebut.

h. Tanggung jawab

Pembentukan karakter tanggung jawab pada materi pemantulan dan penyerapan bunyi terlihat pada saat siswa diberikan tugas oleh guru, mereka berusaha untuk menyelesaikan tugas mereka dengan baik dan sesuai dengan waktu yang telah diberikan oleh guru. Ketika mereka sudah menyelesaikan tugasnya maka artinya mereka sudah memiliki rasa tanggung jawab. 


\section{i. Bersahabat/ komunikatif}

Semua peserta didik pada saat melakukan kegiatan kelompok tentang pemantulan dan penyerapan bunyi mereka terlihat saling bekerja sama untuk memecahkan masalah-masalah yang diberikan oleh guru dan berusaha untuk menyelesaikan secara bersama-sama. Dari sini dapat terlihat karakter bersahabat mereka terhadap antar sesama teman.

j. Toleransi

Guru meminta siswa membentuk kelompok yang beranggotakan 4-5 siswa untuk melakukan sebuah percobaan tentang pemantulan dan penyerapan bunyi. Kelompok dibentuk sesuai dengan nomor urut absen. Guru juga memberi kesempatan kepada semua kelompok untuk menyampaikan hasil diskusi kelompok. Pada materi pemantulan dan penyerapan bunyi, guru memberikan kesempatan kepada peserta didik untuk menanyakan hal-hal yang belum dipahaminya.

Nilai-nilai yang dikembangkan tersebut sesuai dengan nilai karakter yang bersumber dari agama, pancasila, budaya, dan tujuan pendidikan nasional yaitu, religius, jujur, disiplin, toleransi, kerja keras, kreatif, mandiri, demokratis, rasa ingin tahu, semangat kebangsaan, cinta tanah air, menghargai prestasi, bersahabat/komunikatif, cinta damai, gemar membaca, peduli lingkungan, peduli sosial, dan tanggung jawab.

\section{Implementasi Nilai-Nilai Karakter melalui Pembelajaran Contextual Teaching and Learning (CTL) pada Mata Pelajaran Tematik di SD Unggulan 'Aisyiyah Taman Harapan Curup}

Pembelajaran Contextual Taeching and Learning (CTL) pada pelajaran tematik sudah mengintegrasikan nilai-nilai karakter ke dalam setiap kegiatan pembelajaran, mulai kegiatan awal pembelajaran hingga kegiatan akhir pembelajaran.

Pada kegiatan awal pembelajaran, guru mengimplementasikan beberapa kegiatan. Guru memulai kegiatan pembelajaran dengan mengajak siswa untuk berdoa bersama. Namun pada pertemuan kedua guru tidak mengajak siswa untuk berdoa sebelum belajar. Hal ini dikarenakan jam pelajaran tematik yang dilaksanakan pada siang hari. Selain itu, guru mengecek kehadiran siswa sebelum melaksanakan kegiatan pembelajaran.

Pada kegiatan inti pembelajaran, guru menerapkan beberapa metode pembelajaran seperti metode tanya jawab, pemberian tugas, percobaan, dan diskusi kelompok. Hal ini sesuai dengan pendapat yang dikemukakan oleh 
Lickona, menyarankan agar pendidikan karakter berlangsung efektif maka guru dapat mengusahakan implementasi berbagai metode. ${ }^{15}$

Sejalan dengan hal di atas, hasil penelitian Mukhammad Murdiono dalam Novan Ardy (2013) juga menyatakan bahwa cara untuk mengaktifkan peserta didik agar mereka dapat memiliki karakter cerdas, berpikir terbuka, tanggung jawab, dan mempunyai rasa ingin tahu, kita dapat menerapkan hal-hal di bawah ini:

1. Memberi kesempatan kepada peserta didik untuk menjelaskan atau mengemukakan pendapat dan gagasannya, melakukan gerakan dan lain-lain;

2. Meminta peserta didik untuk mengerjakan tugas, misalnya menjawab pertanyaan tertulis, membuat ringkasan, melakukan penelitian, melakukan percobaan, dan sebagainya;

3. Menginstruksikan peserta didik menganalisis, mengevaluasi, dan menyimpulkan sesuatu;

4. Mengajak peserta didik melakukan proses pembelajaran melalui interaksi dengan guru, para pakar, teman, media atau sumber-sumber belajar lainnya.

5. Mengingatkan kepada peserta didik akan pentingnya melakukan pembelajaran melalui diskusi, tanya jawab, mengamati sesuatu proses atau model, dan lain-lain. ${ }^{16}$

Selain itu, dalam kegiatan inti pembelajaran guru memberikan apresiasi kepada peserta didik. Apresiasi ini dapat berupa pemberian penghargaan seperti pemberian point prestasi. Hal ini dapat menciptakan pembelajaran yang menyenangkan dan membuat siswa lebih aktif dalam belajar. Dengan pemberian hadiah tersebut juga dapat membuat kreatifitas siswa berkembang. Sehingga guru dapat mengembangkan potensi-potensi atau kemampuan yang ada pada peserta didik. Dengan suasana kelas demikian dapat mendukung dalam melaksanakan pendidikan karakter. Hal ini sesuai dengan pendapat M. Furqon Hidayatullah, mengatakan bahwa strategi dalam pendidikan karakter dapat dilakukan melalui beberapa sikap, salah satunya yaitu menciptakan suasana yang kondusif. ${ }^{17}$

Pada materi perambatan bunyi guru melaksanakan proses pembelajaran dengan berdiskusi kelompok. Guru membagi siswa sesuai dengan kelompok

15 Muchlas Samani DKK, Konsep Dan Model Pendidikan Karakter ((Bandung: PT. Remaja Rosdakarya, 2011).

16 Ardy Wiyani, Konsep, Praktek \& Strategi Membumikan Pendidikan Karakter Di SD.

${ }^{17}$ Irma Mulyaningsih, "Implementasi Pendidikan Karakter Pada Pembelajaran Tematik Di Kelas IV SD Negeri Pembulan Galur Kulon Progo," Yogyakarta: Universitas Negeri Yogyakarta, 2015), h. 171, 2015, 171. 
belajar yang sudah ditentukan sebelumnya menjadi 3 kelompok. Siswa diberi tugas untuk melakukan percobaan atau praktik tentang perambatan bunyi melalui benda padat, cair, dan gas. Sistem pembentukan kelompok biasanya dilakukan berdasarkan nomor urut absen atau berdasarkan dengan bangku terdekat, sehingga siswa tinggal membalikkan tempat duduk mereka. Tapi terkadang bisa juga dilakukan sesuai dengan kelompok belajar karena memang sudah dibuat kelompok belajar.

Dalam pembentukan kelompok belajar ini merupakan komponen dari pembelajaran Contextual Teaching and Learning (CTL) yaitu masyarakat belajar. Masyarakat belajar adalah kerjasama atau belajar bersama dalam sebuah masyarakat atau kelas-kelompok.

Pada pertemuan ke-1 dalam penyampaian materi perambatan bunyi, guru menggunakan media sebagai alat bantu untuk menyampaikan materi pembelajaran. Dalam materi perambatan bunyi melalui benda padat media atau bahan yang digunakan antara lain, gelas plastik dua buah, benang kasur, dan paku. Kemudian dengan bahan-bahan tersebut dibuat telepon-teleponan. Kemudian perambatan bunyi melalui benda cair bahan yang digunakan ember berisi air, batu, dan corong. Sedangkan perambatan bunyi melalui benda gas, bahan yang digunakan yaitu selang plastik. Bahan-bahan tersebut digunakan guru sebagai media bantu agar siswa dapat mempermudah memahami materi.

Dengan demikian, nilai-nilai karakter kreatif dapat diintegrasikan oleh guru dengan menggunakan media pembelajaran, yang dapat memudahkan siswa untuk memahami materi yang akan dipelajari.

Selain itu, dilakukan juga kegiatan tanya jawab dengan peserta didik terkait dengan materi yang sedang dipelajari. Guru sering menerapkan metode tanya jawab dengan peserta didik. Guru bertanya tentang materi, siswa menjawab sesuai dengan pengetahuan mereka, dan sebaliknya. Pada materi perambatan bunyi guru bertanya jawab dengan peserta didik tentang energi bunyi dan perpindahan bunyi. Aspek tanya jawab merupakan salah satu komponen dari pembelajaran Contextual Teaching and Learning (CTL).

Guru memberikan kepercayaan pada peserta didik dalam mengerjakan tugas. Pada materi perambatan bunyi, guru memberikan tugas diskusi untuk melakukan percobaan tentang perambatan bunyi melalui benda padat, cair, dan gas. Hal ini dapat memunculkan daya fikir kreatif siswa. Dengan pemberian tugas tersebut maka peserta didik akan berusaha untuk memecahkan masalah tersebut dan menemukan jawaban dari permasalahan yang diberikan. 
Setelah melakukan kegiatan diskusi kelompok, guru meminta perwakilan kelompok untuk mempersentasikan hasil diskusi. Hal ini dilakukan agar mereka bisa menyajikan hasil diskusi yang telah mereka dapatkan dan bertujuan untuk melatih keberanian siswa dalam berkomunikasi serta meningkatkan rasa percaya diri.

Selain itu, dalam pembelajaran Contextual Teaching and Learning (CTL) pada materi perambatan bunyi yang menggunakan diskusi kelompok juga memiliki nilai karakter peduli sosial. Terlihat bahwa dalam kegiatan kelompok siswa saling tolong menolong dan bekerja sama dalam menyelesaikan tugas kelompok, sehingga sistem pembelajaran pada materi perambatan bunyi guru memberikan penugasan dalam bentuk tugas individu dan kelompok. Tugas individu pada materi perambatan bunyi diberikan dalam bentuk latihan soal atau pre-test di akhir pembelajaran. Sedangkan tugas kelompok diberikan dalam bentuk tugas percobaan tentang perambatan bunyi melalui benda padat, cair dan gas.

Dengan demikian, penanaman nilai karakter tenggung jawab dapat dilihat melalui pemberian tugas individu atau kelompok, ketika mereka sudah menyelesaikan tugas artinya mereka sudah memiliki rasa tanggung jawab. Sedangkan karakter peduli sosial ditanamkan dalam kegiatan belajar kelompok.

Berdasarkan hasil observasi, peneliti melihat bahwa semua siswa berusaha menyelesaikan tugas yang diberikan dengan baik dan menyelesaikan sesuai dengan waktu yang telah diberikan. Serta saling tolong menolong serta bekerja sama dalam menyelesaikan tugas percobaan tentang perambatan bunyi melalui benda padat, cair dan gas.

Guru memberikan penghargaan berupa poin prestasi yang ditulis didalam buku saku siswa dan penilaian hasil kerja siswa. Penghargaan ini di berikan ketika guru membuat kriteria tertentu dalam penugasan. Pada materi perambatan bunyi, guru memberikan penghargaan poin prestasi kepada siswa yang bisa menyimpulkan hasil pembelajaran dan kelompok terbaik. Dengan adanya penghargaan siswa menjadi lebih aktif dan memiliki antusias yang tinggi selama pembelajaran.

Siswa senang mendapatkan point prestasi, sehingga hampir setiap penugasan mereka minta untuk diberikan point prestasi tersebut. Selain itu, mereka juga senang memberikan hadiah kecil-kecilan atas apa yang telah mereka kerjakan. 
Selanjutnya dalam hal kedisiplinan, guru melatih siswa untuk disiplin dalam masuk kelas dengan tepat waktu. Serta memberikan keteladanan dengan memberikan contoh dari segi berpenampilan, dengan cara menggunakan seragam yang rapi dan sesuai dengan peraturan yang sudah ditetapkan seperti menggunakan baju batik dan baju seragam lainnya. Hal ini sesuai dengan pendapat Puskur yang mengatakan bahwa, keteladanan merupakan sikap "menjadi contoh". Sikap menjadi contoh merupakan prilaku dan sikap guru dan tenaga kependidikan dan siswa dalam memberikan contoh mealui tindakantindakan yang baik sehingga diharapkan menjadi panutan bagi siswa lain. ${ }^{18}$

Adapun implementasi pendidikan karakter melalui pembelajaran Contextual Teaching and Learning (CTL) pada pelajaran tematik dapat dilihat pada tabel berikut:

\section{Tabel 2. Implementasi Nilai-Nilai Karakter Siswa Melalui Pembelajaran Contextual Teaching and Learning (CTL) pada Materi Perambatan Bunyi}

\begin{tabular}{|c|c|c|c|}
\hline No & $\begin{array}{l}\text { Nilai-nilai } \\
\text { karakter }\end{array}$ & Kegiatan & Aspek CTL \\
\hline \multirow[t]{3}{*}{1.} & Religius & $\begin{array}{l}\text { Mengucapkan salam dan berdo'a sebelum dan } \\
\text { sesudah pembelajaran }\end{array}$ & \multirow{3}{*}{ - } \\
\hline & & $\begin{array}{l}\text { Tadarusan atu membaca iqra' sebelum } \\
\text { memulai pembelajaran }\end{array}$ & \\
\hline & & Sholat dhuha berjama'ah & \\
\hline \multirow[t]{3}{*}{2.} & Disiplin & Mengecek kehadiran siswa & - \\
\hline & & $\begin{array}{l}\text { Menggunakan seragam guru sesuai dengan } \\
\text { aturan }\end{array}$ & \multirow[t]{2}{*}{ Pemodelan } \\
\hline & & Guru masuk kelas tepat waktu & \\
\hline \multirow[t]{2}{*}{3} & Kerja keras & $\begin{array}{l}\text { Meminta peserta didik untuk bisa } \\
\text { menyelesaikan tugas dengan tepat waktu }\end{array}$ & - \\
\hline & & $\begin{array}{l}\text { Memberikan kesempatan kepada peserta didik } \\
\text { untuk malakukan percobaan tentang } \\
\text { perambatan bunyi }\end{array}$ & Menemukn / inquiry \\
\hline \multirow[t]{4}{*}{4} & Kreatif & $\begin{array}{l}\text { Pemberian tugas yang menantang dapat } \\
\text { memunculkan daya fikir kreatif }\end{array}$ & Konstruktivisme \\
\hline & & Menggunakan media pembelajaran & Pemodelan \\
\hline & & $\begin{array}{l}\text { Mengajukan berbagai pertanyaan berkenaan } \\
\text { dengan materi perambatan bunyi untuk } \\
\text { memancing gagasan siswa }\end{array}$ & Tanya jawab \\
\hline & & Menggunakan berbagai penilaian & - \\
\hline \multirow[t]{2}{*}{5} & Mandiri & $\begin{array}{l}\text { Meminta peserta didik untuk menyelesaikan } \\
\text { tugas-tugas yang diberikan secara individu. }\end{array}$ & - \\
\hline & & $\begin{array}{l}\text { Meminta peserta didik } \\
\text { mempersentasikan hasil diskusi }\end{array}$ & Masyarakat belajar \\
\hline
\end{tabular}

18 Narwanti, Pendidikan Karakter. 


\begin{tabular}{|c|c|c|c|}
\hline 6 & Rasa ingin tahu & $\begin{array}{l}\text { Mengajukan pertanyaan-pertanyaan terkait } \\
\text { dengan perambatan bunyi }\end{array}$ & Tanya jawab \\
\hline 7 & Cinta tanah air & Menyanyikan lagu indonesia & Refleksi \\
\hline 8 & $\begin{array}{l}\text { Menghargai } \\
\text { prestasi }\end{array}$ & $\begin{array}{l}\text { Memberi penghargaan atas hasil karya siswa } \\
\text { Memberikan penilaian terhadap hasil belajar } \\
\text { siswa. }\end{array}$ & - \\
\hline 9 & Peduli sosial & 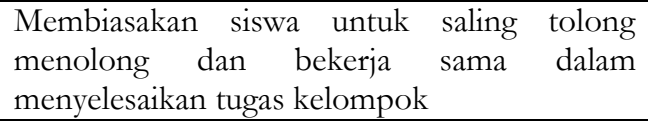 & Masyarakat belajar \\
\hline 10 & $\begin{array}{l}\text { Tanggung } \\
\text { jawab }\end{array}$ & $\begin{array}{l}\text { Membiasakan siswa untuk mengerjakan soal } \\
\text { latihan/tugas percobaan yang diberikan }\end{array}$ & $\begin{array}{l}\text { Penilaian autentik, } \\
\text { masyarakat belajar }\end{array}$ \\
\hline 11 & $\begin{array}{l}\text { Bersahabat/ } \\
\text { komunikatif }\end{array}$ & $\begin{array}{l}\text { Diskusi kelompok untuk memecahkan suatu } \\
\text { masalah mengenai perambatan bunyi }\end{array}$ & nquiry/menemukan \\
\hline 12 & Toleransi & $\begin{array}{l}\begin{array}{l}\text { Membagi siswa bekerja kelompok yang } \\
\text { berbeda }\end{array} \\
\end{array}$ & Masyarakat belajar \\
\hline
\end{tabular}

Dalam pelaksanaan pembelajaran Contextual Teaching and Learning (CTL) pada pelajaran tematik terdapat beberapa karakter yang belum dikembangkan dalam kegiatan pembelajaran. Nilai-nilai karakter tersebut adalah jujur, demokrasi, semangat kebangsaan, cinta damai, gemar membaca, dan peduli lingkungan. Guru semestinya mengintegrasikan nilai-nilai karakter tersebut dalam kegiatan pembelajaran, seperti mengawasi siswa pada saat mengerjakan soal latihan secara individu dan meminta siswa untuk mengerjakan soal secara mandiri. Meminta peserta didik untuk mencari sumber lain tentang materi yang akan dipelajari, menciptakan pembelajaran yang dialogis dan interaktif. Serta meminta peserta didik untuk membersihkan lingkungan kelas setelah melaksanakan kegiatan praktek.

\section{KESIMPULAN}

Berdasarkan hasil penelitian, berikut ini ada dua belas nilai karakter yang dikembangkan oleh guru, yaitu: 1) Religius: Nilai ini terlihat pada saat guru mengajak siswa untuk berdoa sebelum dan sesudah pembelajaran, tadarusan atau belajar iqra'. Serta guru membiasakan siswa untuk melaksanakan sholat dhuha sebelum melakukan kegiatan pembelajaran; 2) Toleransi: Nilai ini terlihat pada saat guru membagi sisiwa untuk bekerja dalam kelompok yang berbeda. Pembentukan kelompok dilakukan berdasarkan nomor urut absen atau berdasarkan dengan bangku terdekat. Serta dibentuk sesuai dengan kelompok belajar yang sudah ditentukan sebelumnya atau memberi kesempatan kepada peserta didik untuk memilih kelompoknya sendiri. Serta terlihat pada saat guru memberikan refleksi setelah melakukan proses pembelajaran, dengan memberikan kepada siswa untuk menanyakan hal-hal yang belum mereka 
pahami; 3) Disiplin: Nilai ini terlihat pada saat guru mengecek kehadiran siswa diawal pembelajaran. Serta dalam penanaman karakter disiplin Guru memberikan contoh seperti menggunakan seragam sesuai dengan aturan yang sudah ditantukan seperti, memakai baju batik atau baju seragam lainnya, dan masuk kelas dengan tepat waktu; 4) Kerja keras: : Nilai ini terlihat pada saat siswa menyelesaikan tugas yang diberikan, baik tugas individu maupun tugas kelompok; 5) Kreatif: Nilai ini terlihat pada saat guru mengajukan berbagai pertanyaan-pertanyaan yang berkenaan dengan materi, pemberian tugas. Serta dalam penyampaian materi guru menggunakan media pembelajaran dan menggunakan berbagai alat penilaian; 6) Mandiri: Nilai ini terlihat pada saat guru memberikan latihan-latihan soal secara mandiri. Serta terlihat pada saat siswa mempersentasikan hasil diskusi kelompok; 7) Rasa ingin tahu: Nilai ini terlihat pada saat guru memberikan apersepsi berupa pertanyaan-pertanyaan yang berkaitan dengan materi sebelum memasuki inti pembelajaran; 8) Cinta tanah air: Nilai ini terlihat pada saat guru mengajak siswa untuk menyanyikan lagu kebangsaan Indonesia Raya sebelum belajar dan menyanyikan lagu-lagu daerah sebelum pulang; 9) Menghargai prestasi: Nilai ini terlihat pada saat guru memberikan penilaian hasil kerja siswa dan memberikan hadiah kepada siswa berupa point prestasi yang dituliskan kedalam buku saku siswa; 10) Bersahabat/komunikatif: Nilai ini terlihat pada saat guru meminta untuk melakukan kegiatan diskusi kelompok untuk memecahkan masalah atau tugas yang diberikan; 11)Peduli sosial: Nilai ini terlihat pada saat siswa diberikan tugas kelompok. Hal ini dapat membiasakan siswa untuk saling tolong menolong dan bekerja sama dalam menyelesaikan tugas yang diberikan; 12) Tanggung jawab.

Dalam pelaksanaan pembelajaran Contextual Teaching and Learning (CTL) pada pelajaran tematik terdapat beberapa karakter yang belum dikembangkan dalam kegiatan pembelajaran. Nilai-nilai karakter tersebut adalah jujur, demokrasi, semangat kebangsaan, cinta damai, gemar membaca, dan peduli lingkungan.

\section{DAFTAR PUSTAKA}

Ardy Wiyani, Novan. Konsep, Praktek \& Strategi Membumikan Pendidikan Karakter Di SD. Jogjakarta: Ar-Ruzz Media, 2013.

Hamdani. Dasar-Dasar Kependidikan. Bandung: CV Pustaka Setia, 2011.

Heri, Gunawan. Pendidikan Karakter. Bandung: Alfabeta, 2012.

Ma'mur Asmani, Jamal. Buku Panduan Internalisasi Pendidikan Karakter Di Sekolah. Yogyakarta: DIVA Press, 2012. 
Muhaimin Azzet, Akhmad. Urgensi Pendidikan Karakter Di Indonesia. Jogjakarta: Ar-Ruzz Media, 2011.

Mulyaningsih, Irma. "Implementasi Pendidikan Karakter Pada Pembelajaran Tematik Di Kelas IV SD Negeri Pembulan Galur Kulon Progo." Yogyakarta: Universitas Negeri Yogyakarta, 2015), h. 171, 2015, 171.

Mulyasa. Pengembangan Dan Implementasi Kurikulum 2013. Bandung: PT remaja Rosdakarya, 2014.

Narwanti, Sri. Pendidikan Karakter. Yogyakarta: Familia, 2011.

Rusman. Belajar \& Pembelajaran: Berorientasi Standar Proses Pendidikan. Jakarta: Kencana, 2017.

Samani DKK, Muchlas. Konsep Dan Model Pendidikan Karakter. (Bandung: PT. Remaja Rosdakarya, 2011.

Samani, Muchlas, and Harianto. Konsep Dan Model Pendidikan Karakter,. Bandung: PT remaja Rosdakarya, 2013.

Samriani. "Penerapan Pendekatan Contextual Teaching And Learning (CTL) Dalam Meningkatkan Hasil Belajar Siswa Pada Mata Pelajaran IPA Di Kelas IV SD No 3 Siwalempu." Fakultas Keguruan Dan Ilmu Pendidikan Universitas Tadulako 4, no. 2 (n.d.): 57.

Sanjaya, Wina. Strategi Pembelajaran Berorientasi Standar Proses Pendidikan. Jakarta: Kencana, 2016.

Suryatri Darmiatu, Daryanto. Implementasi Pendidikan Karakter Di Sekolah. Yogyakarta: Gava Media, 2013.

Wawancara dengan Waka Kurikulum SDUA (SD Unggulan 'Aisyiyah Taman Harapan Curup), February 5, 2018.

Widyaningrum, Retno. Model Pembelajaran Tematik Di MI/SD. No. 01. Vol. Vol. 10. Ponorogo: STAIN Ponorogo, 2012.

Yamin, Martinis. Sertifikasi Profesi Keguruan Di Indonesia. (Jakarta: Gaung Persada Press, 2007. 